\title{
Somatic cell nuclear transfer alters peri-implantation trophoblast differentiation in bovine embryos
}

\author{
Daniel R Arnold ${ }^{1}$, Vilceu Bordignon ${ }^{1}$, Réjean Lefebvre ${ }^{1,2}$, Bruce D Murphy ${ }^{1}$ and \\ Lawrence C Smith ${ }^{1}$ \\ ${ }^{1}$ Centre de recherche en reproduction animale, and ${ }^{2}$ Départment de sciences cliniques, Faculté de médecine \\ vétérinaire, Université de Montréal, St-Hyacinthe, Québec, Canada J2S 7C6
}

Correspondence should be addressed to L C Smith; Email: smithl@medvet.umontreal.ca

D R Arnold is now at Department of Obstetrics and Gynecology, McGill University Health Centre, Montreal, Québec, Canada $\checkmark$ Bordignon is now at Department of Animal Science, McGill University, Montreal, Québec, Canada

\begin{abstract}
Abnormal placental development limits success in ruminant pregnancies derived from somatic cell nuclear transfer (SCNT), due to reduction in placentome number and consequently, maternal/fetal exchange. In the primary stages of an epithelial-chorial association, the maternal/fetal interface is characterized by progressive endometrial invasion by specialized trophoblast binucleate/giant cells (TGC). We hypothesized that dysfunctional placentation in SCNT pregnancies results from aberration in expression of genes known to be necessary for trophoblast proliferation (Mash2), differentiation (Hand1), and function (IFN- $\tau$ and PAG-9). We, therefore, compared the expression of these factors in trophoblast from bovine embryos derived from artificial insemination (AI), in vitro fertilization (IVF), and SCNT prior to (day 17) and following (day 40 of gestation) implantation, as well as TGC densities and function. In preimplantation embryos, Mash2 mRNA was more abundant in SCNT embryos compared to AI, while Hand1 was highest in AI and IVF relative to SCNT embryos. IFN- $\tau$ mRNA abundance did not differ among groups. PAG-9 mRNA was undetectable in SCNT embryos, present in IVF embryos and highest in AI embryos. In postimplantation pregnancies, SCNT fetal cotyledons displayed higher Mash2 and Hand1 than AI and IVF tissues. Allelic expression of Mash2 was not different among the groups, which suggests that elevated mRNA expression was not due to altered imprinting status of Mash2. The day 40 SCNT cotyledons had the fewest number of TGC compared to IVF and AI controls. Thus, expression of genes critical to normal placental development is altered in SCNT bovine embryos, and this is expected to cause abnormal trophoblast differentiation and contribute to pregnancy loss. Reproduction (2006) 132 279-290
\end{abstract}

\section{Introduction}

Somatic cell nuclear transfer (SCNT) has been employed to produce clones of a wide variety of mammalian species since the first successful use of differentiated donor cells was reported (Wilmut et al. 1997). However, the success of cloning by nuclear transfer has not come without complication. In the 10 years of SCNT research, the efficiency of this technique has not improved. Several elegant studies have been conducted to increase the proportion of reconstructed embryos that develop to blastocysts and determine altered gene expression compared to IVF blastocysts (for review, see Heyman 2005, Wrenzycki et al. 2005). Unfortunately, fewer than $6 \%$ of the reconstructed bovine blastocysts develop into viable offspring (Hill et al. 2000a). From the time of embryo transfer (day 8 ) to day 90 of gestation, $80 \%$ of
SCNT pregnancies are lost (Hill et al. 2000b). A major problem associated with the mortality of these reconstructed embryos is poor placental development (Hill et al. 2000b, De Sousa et al. 2001, Ono et al. 2001a, 2001b, Ogura et al. 2002).

Some of the most common placental anomalies associated with SCNT pregnancies in ruminants are a reduced number of placentomes, poor vascular development, hydroallantois, enlarged placentomes, and increased fetal membrane weights in the later stages of gestation (Wells et al. 1999, Hill et al. 2000b, Hashizume et al. 2002). Abnormal placental development has also been reported earlier in gestation, during the critical time of early postimplantation. Hill et al. $(2000 b)$ observed reduced vascularity and epithelial height in the placentomal regions of SCNT pregnancies at days 45-55. In addition, day 60 SCNT bovine 
pregnancies had less organized fetal villi development and fewer placentomes compared to Al pregnancies (Hashizume et al. 2002). These defects suggest aberrant developmental processes in SCNT placentas.

As with other species of mammals, the first cellular differentiation of the bovine embryo occurs with the formation of the blastocyst, resulting in the inner cell mass and trophoblast cells that will develop into the embryo proper and extra-embryonic tissues, respectively (McLaren 1990). As pregnancy ensues, ruminant trophoblast cells proliferate and differentiate into either mononucleate or binucleate/giant cells (Wooding \& Wathes 1980). The mononucleate population comprises the majority of the trophoblast contribution to the placenta, and these cells are involved in the production of interferon- $\tau$, (IFN- $\tau)$, the pregnancy recognition signal in cattle (Roberts et al. 1992). The trophoblast binucleate/ giant cells (TGC), which makes up approximately $20 \%$ of the trophoblast population, migrate across the fetomaternal junction and fuse with uterine epithelial cells (Wooding \& Wathes 1980, Klisch et al. 1999). These TGC undergo acytokinetic mitosis to become tetraploid, and may also undergo endoreduplication, with a resultant DNA content that can be as high as $32 \mathrm{~N}$ (Klisch et al. 1999). These cells produce pregnancy-related proteins, such as pregnancy-associated glycoproteins (PAGs), placental lactogen $(\mathrm{PL})$, and prolactin-related proteins, all are detectable in the maternal serum as pregnancy progresses (Wooding 1981, Kessler \& Schuler 1991, Zoli et al. 1992).

Reports on TGC populations in SCNT placentas have ranged from fewer (Hashizume et al. 2002), no difference (Hoffert et al. 2005), or more (Ravelich et al. 2004a) when compared to IVF and $\mathrm{Al}$ placentas from early gestation (days 30-60). Even though these results are in conflict, they clearly indicate that trophoblast development in SCNT embryos is altered. In addition, the mRNA and protein levels for gene associated with TGC function such as PL and PAG vary between naturally derived and SCNT placentas (Hashizume et al. 2002, Patel et al. 2004b, Ravelich et al. 2004b, Hoffert et al. 2005). Given the morphological variation and consequent dysfunction of TGC in placentas from SCNT embryos, it is of considerable interest to explore the expression of factors involved in bovine trophoblast differentiation during the early stages of placental formation.

Most of the work till date has been focused on the expression of bovine genes at the blastocyst stage where experimental samples are more readily available. It is highly possible that many genes, which regulate later stages of trophoblast development, are not expressed at this stage. Moreover, while there are numerous morphological descriptions of bovine TGC, there are few studies in gene regulation during bovine TGC differentiation. Further, the majority of the genes driving trophoblast differentiation in the cow is not known, so investigators had to rely on the information gleaned from other species. Gene inactivation studies in mice have identified two genes that are essential to trophoblast differentiation: mammalian achaete-scute complex homologue-like 2 (Mash2; also known as Ascl2; Guillemot et al. 1994) and heart and neural crest cell derivative 1 (Hand1; Cross et al. 1995). Both genes are basic helix-loop-helix transcription factors, and appear to have opposing activities (Cross et al. 1995). In the mouse, Mash2 stimulates cell proliferation and inhibits progression of trophoblast to its terminally differentiated giant cell form (Cross et al. 1995, Tanaka et al. 1997, Rossant et al. 1998), whereas Hand1 evokes giant cell formation (Riley et al. 1998). Mash2 homozygous mutant mouse embryos, which are lost during midgestation period (day 9.5 postcoitum) have excessive number of trophoblast giant cells (Guillemot et al. 1994). Embryos from mice with mutated Hand1 have reduced numbers of giant cells and pregnancy is also lost during mid-gestation period (Riley et al. 1998). In the cow, we have shown Mash2 to be expressed specifically in the placenta, and in greatest abundance during the time of trophoblast proliferation prior to implantation (Arnold et al. 2006). As in the mouse (Guillemot et al. 1995), bovine Mash2 is an imprinted gene with the paternal allele silenced after implantation (Arnold et al. 2006).

The goal of the present study was to examine these genes of known significance to trophoblast differentiation and function during the pre- and early postimplantation periods of the cow and to determine how their expression correlates with the TGC population in placental tissues of $\mathrm{Al}$, IVF, and SCNT produced embryos.

\section{Materials and Methods}

\section{Animals}

All animal treatment protocols were approved by the Comité de déontologie, Faculté de médecine vétérinaire, Université de Montréal in accordance with regulations of the Canadian Council of Animal Care. Mature ( $>2$ years of age) Holstein cows were chosen as recipients.

\section{Oocyte collection and in vitro maturation (IVM)}

Oocytes obtained from slaughterhouse ovaries were matured in vitro as previously described (Bordignon et al. 2003). Briefly, cumulus-oocyte complexes (COC) were aspirated from 2 to $7 \mathrm{~mm}$ follicles and washed in HEPES-buffered tissue culture medium (TCM)-199 (Invitrogen Life Technologies) supplemented with $10 \%$ fetal bovine serum (FBS). Only COCs with several layers of cumulus cells and with homogenous oocyte cytoplasm were selected. Groups of 25 COCs were cultured in $100 \mu \mathrm{l}$ drops of IVM media (bicarbonate-buffered TCM199 supplement with $10 \%$ FBS, $50 \mu \mathrm{l} / \mathrm{ml}$ luteinizing hormone (LH) (Ayerst, London, Ontario, Canada), $0.5 \mu \mathrm{g} /$ $\mathrm{ml}$ follicle-stimulating hormone (FSH) (Follitropin-V; 
Vetrepharm, St-Laurent, PQ, Canada), $1 \mu \mathrm{g} / \mathrm{ml}$ estradiol$17 \beta$ (Sigma), $22 \mu \mathrm{g} / \mathrm{ml}$ pyruvate (Sigma), and $50 \mu \mathrm{g} / \mathrm{ml}$ gentamicin (Sigma)). After 20-22 h of IVM, matured COCs were randomly assigned to either IVF or SCNT groups.

\section{Production of somatic cell nuclear transfer embryos (SCNT)}

Cumulus cells were removed from oocytes with a $0.2 \%$ hyaluronidase (Sigma) solution and oocytes with the first polar body present were selected for nuclear transfer as previously described (Bordignon et al. 2003). Briefly, cumulus-denuded oocytes were placed in PBS containing $7.5 \mu \mathrm{g} / \mathrm{ml}$ cytochalasin B (Sigma) and approximately $30 \%$ of the host cytoplasm adjacent to the first polar body was removed. To confirm the removal of chromatin, host oocytes were placed in medium containing $5 \mu \mathrm{g} / \mathrm{ml}$ Hoechst 33342 (Sigma) for $15 \mathrm{~min}$ and subjected briefly to u.v. irradiation.

A primary fibroblast cell line from a Bos taurus $\times$ Bos indicus male fetus collected at 60 days of gestation, was used for SCNT. Donor cells were cultured in Dulbecco's modified Eagles medium supplemented with $10 \% \mathrm{FBS}$ and 50 units/ml penicillin-streptomycin (Invitrogen) at $39{ }^{\circ} \mathrm{C}$ in a humidified atmosphere of $5 \% \mathrm{CO}_{2}$. Donor cultures between two and five passages were allowed to progress to confluence and maintained for 2 days prior to use so cells would be in the $\mathrm{G} 1 / \mathrm{G} 0$ stage of the cell cycle. A single fetal fibroblast cell was introduced into the perivitelline space of the enucleated oocyte. The resulting couplet was placed in a $0.3 \mathrm{M}$ mannitol solution containing $0.1 \mathrm{mM} \mathrm{MgSO}_{4}$ and $0.05 \mathrm{mM} \mathrm{CaCl}_{2}$ and subjected to a $1.5 \mathrm{kV}$ electric pulse lasting $70 \mu \mathrm{s}$. Couplets were then washed and placed into $50 \mu \mathrm{l}$ drops of modified synthetic oviductal fluid (mSOF: $108 \mathrm{mM} \mathrm{NaCl}, 7.2 \mathrm{mM} \mathrm{KCl}, 0.5 \mathrm{mM} \mathrm{MgCl} 2,2.5 \mathrm{mM}$ $\mathrm{NaHCO}_{3}, 1.7 \mathrm{mMCaCl} \cdot \mathrm{H}_{2} \mathrm{O}, 0.5 \mathrm{mM}$ glucose $0.33 \mathrm{mM}$ pyruvic acid, $3 \mathrm{mM}$ lactic acid, $8 \mathrm{mg} / \mathrm{ml} \mathrm{BSA}, 150 \mu \mathrm{g} / \mathrm{ml}$ gentamicin, $0.01 \%$ phenol red, $1.4 \mathrm{mM}$ glycine, $0.4 \mathrm{mM}$ alanine, $1 \mathrm{mM}$ glutamine, $2 \%$ essential amino acids, and $1 \%$ non-essential amino acids; Gardner et al. 1994). After $1-2 \mathrm{~h}$ in culture, couplets were examined to determine fusion and exposed to $5 \mathrm{mM}$ ionomycin (Sigma) for $4 \mathrm{~min}$ to induce parthenogenetic activation. Reconstructed oocytes were cultured in $\mathrm{mSOF}$ at $39^{\circ} \mathrm{C}$ in a humidified atmosphere of $5 \% \mathrm{CO}_{2}$ and $5 \% \mathrm{O}_{2}$ for 7 days.

\section{Production of in vitro (IVF) and in vivo embryos (AI)}

For IVF embryos, matured COCs were fertilized as previously described (Parrish et al. 1986) and cultured in $\mathrm{mSOF}$ at $39^{\circ} \mathrm{C}$ in a humidified atmosphere of $5 \% \mathrm{CO}_{2}$ and $5 \% \mathrm{O}_{2}$ for 7 days. For Al embryos, Holstein cows were either injected with $500 \mu \mathrm{g}$ cloprostenol (Estrumate, Schering-Plough Animal health, Pointe-Claire, Quebec, Canada) to induce estrus and artificially inseminated or subjected to a superovulation protocol as previously described (Price et al. 1999). Briefly, cows were given i.m. injections of Follitropin-V (Vetrepharm) every $12 \mathrm{~h}$ in decreasing doses starting at days 9-10 of the estrous cycle (day $0=$ estrus). Cows then received an injection of $500 \mu \mathrm{g}$ cloprostenol at $52 \mathrm{~h}$ and were artificially inseminated at $86 \mathrm{~h}$ after the initiation of superovulation respectively. Semen used for AI and IVF was from the same Bos indicus bull used to produce the day 60 fetal donor cells.

\section{Production and collection of day 17 embryos and day 40 tissues}

On day 8 of in vitro culture, blastocyst stage SCNT and IVF embryos were non-surgically transferred into synchronized Holstein cows. For day 17 embryo collections, 10-12 embryos were transferred per recipient. For day 40 samples, 1-2 embryos were transferred per recipient. At day 17 of pregnancy, filamentous embryos were collected from recipients or superovulated cows (AI group) by non-surgical flushing of the uterus with sterile PBS $+0.4 \%$ BSA. Embryos were snap-frozen and stored at $-70{ }^{\circ} \mathrm{C}$ until further processed. For day 40 samples, pregnancy was confirmed via ultrasonography, animals were slaughtered and pregnant uteri with viable fetuses were collected at the abattoir and transported on ice to the laboratory. For each gravid uterus, intercotyledonary tissue and four cotyledons were collected and fixed with $10 \%$ buffered formalin. The remaining cotyledons were snap-frozen and stored at $-70^{\circ} \mathrm{C}$ until further processed.

\section{RNA extraction, purification, and reverse transcriptase $(R T)$ reaction}

Individual day 17 embryos were homogenized and RNA was purified using TRIzol LS Reagent (Invitrogen) as recommended by the manufacturer. Day 40 tissues were homogenized in buffer RLT (Qiagen) with $0.12 \mathrm{M}$ $\beta$-mercaptoethanol (Sigma) and RNA was purified using an RNeasy Protect Mini kit (Qiagen), as recommended by the manufacturer. Total RNA was measured by spectrophotometry at $260 \mathrm{~nm}$ and $1.0 \mu \mathrm{g} / \mathrm{sample}$ of total RNA was used for the RT reaction using the Moloney murine leukemia virus (M-MLV) RT (Promega Biosciences, Inc.) according to manufacturer's instructions.

\section{Quantitative RT-PCR}

For the analysis of relative mRNA abundance, bovine-specific primers for Mash2 (GenBank Accession No. DQ333219), IFN- $\tau$ (GenBank Accession No. AF270471), and PAG-9 (GenBank Accession No. AF020511) were developed (Table 1). Bovine-specific primers for glyceraldehyde 3-phosphate dehydrogenase (Gapdh; GenBank Accession No. AF077815) were used as an internal control. 
Table 1 Oligonucleotide primer sequences used for reverse transcriptase-PCR.

\begin{tabular}{|c|c|c|c|}
\hline Gene & Primer $\left(5^{\prime}-3^{\prime}\right)$ sense and antisense & Length (bp) & Annealing temperature $\left({ }^{\circ} \mathrm{C}\right)$ \\
\hline Gapdh & $\begin{array}{l}\text { TGTTCCAGTATGATTCCACCC } \\
\text { TCCACCACCCTGTTGCTGTA }\end{array}$ & 791 & 58 \\
\hline Hand1 & $\begin{array}{l}\text { GCTCTCCAAGATCAAGACTCTGC } \\
\text { CGGTGCGTCCTTTAATCCTCTTC }\end{array}$ & 224 & 58 \\
\hline IFN- $\tau$ & $\begin{array}{l}\text { GCTATCTCTGTGCTCCATGAGATG } \\
\text { AGTGAGTTCAGATCTCCACCCATC }\end{array}$ & 353 & 58 \\
\hline Mash2 & $\begin{array}{l}\text { CGCTGCGCTCGGCGGTTGAGTA } \\
\text { GGGACCCGGGCTCCGAGCTGTG }\end{array}$ & 210 & 67.5 \\
\hline PAG-9 & $\begin{array}{l}\text { TCCTTTTGTACCATGCCAGC } \\
\text { TGCCCTCCTGCTTGTTTTTG }\end{array}$ & 330 & 58 \\
\hline
\end{tabular}

Hand1 primers (Table 1) were designed based on the homologous sequences between the human (GenBank Accession No. NM004821) and mouse (GenBank Accession No. NM008213; Table 1). PCR products of the expected size were excised and purified using a Gel Extraction kit (Qiagen). Purified cDNA was then ligated into a pGEM-T Easy Vector System I (Promega Corp.) according to manufacturer's instructions, and further transformed into competent Escherichia coli strain XL-1 blue. Plasmids were isolated by the use of a QIAprep Spin Miniprep kit (Qiagen) and sequenced using a ABI PRISM 310 sequencer (Applied Biosystems, Foster City, CA, USA), and at least three independent samples were sequenced for the verification of authenticity. Sequences were analyzed against known homologous Hand1 sequences and submitted to GenBank (Accession No. DQ381724).

Steady-state amounts of mRNA were analyzed using specific quantitative RT-PCR (qRT-PCR) assays (Itoh et al. 1998). Briefly, PCR products using gene-specific primers (Table 1) were gel extracted and pooled using Qiaquick Gel Extraction and QIAquick Purification kits respectively (Qiagen) to generate standard curves ranging from 0.01 to $100 \mathrm{fg} / \mu \mathrm{l}$. Five known standard concentrations and samples were subjected to PCR amplification consisting of an initial denaturing $\left(95^{\circ} \mathrm{C} / 5 \mathrm{~min}\right)$, cycles of denaturing $\left(94^{\circ} \mathrm{C} / 30 \mathrm{~s}\right.$ ), annealing (primer-specific temp/30 s) and elongation $\left(72{ }^{\circ} \mathrm{C} / 30 \mathrm{~s}\right)$, and a final elongation $\left(72{ }^{\circ} \mathrm{C} / 4 \mathrm{~min}\right)$. Optimal cycle number for amplification during the exponential phase was determined for each gene. Cycle numbers for day 17 samples were: Gapdh, 19; Mash2, 27; Hand1, 27; IFN- $\tau$, 15; and PAG-9, 40. For day 40 cotyledonary tissue, 20, 35 , and 26 cycles were used for Gapdh, Mash2, and Hand1 respectively. PCR products were analyzed with SYBR Safe (Invitrogen) and calculated with a computer imaging system utilizing the Macintosh NIH software (National Institute of Health, Bethesda, MD, USA).

\section{Determination of parental allele expression of Mash2}

To determine the parental allele expression of Mash2, a PCR-restriction fragment length polymorphism (PCRRFLP) assay was utilized as previously described (Arnold et al. 2006). Briefly, a 210 bp Mash2 PCR product from Bos taurus (BT) and Bos indicus (BI) cotyledonary tissues were excised, purified, and sequenced as described earlier. A single polymorphism was detected (T/C) between the $\mathrm{BT}$ and $\mathrm{BI}$ sequences. The polymorphism was within the recognition site of the restriction enzyme Sfil, which allowed the paternal allele (BI) to be digested (giving two bands of 135 and $75 \mathrm{bps}$ ), whereas the maternal allele (BT) remained intact (Fig. 4A). PCR products from day 17 and day $40 \mathrm{Al}$, IVF, and SCNT samples were digested with Sfil at $50{ }^{\circ} \mathrm{C}$ for $15 \mathrm{~h}$.

\section{Determination of trophoblast binucleate/giant cells density and function}

To determine the proportion of TGC in the trophoectoderm, formalin-fixed cotyledonary tissues were embedded in paraffin and sectioned at $4 \mu \mathrm{m}$. Slides were stained by periodic acid-Schiff (PAS) and counterstained with hematoxylin to aid in the identification of multinucleate giant cells as previously described (Klisch et al. 1999). For each slide, cells were counted from five randomly selected microscope fields at $400 \times$ magnification. Cell counting was performed using a procedure with animal and treatment unknown to the examiner.

To confirm TGC numbers and function, a monoclonal antibody, SBU-3 (kindly provided by Garry Barcham, University of Melbourne, Victoria, Australia) raised against sheep trophoblast microvillous preparation that recognizes ruminant binucleate cells (Lee et al. 1985) was used. The same antibody has been used previously to characterize binucleate cell distribution in bovine placentomes (Lee et al. 1986). After washes in PBS, sections were incubated with a CY3 fluorochromelabeled secondary antibody (Jackson ImmunoResearch, West Grove, PA, USA). Nuclei were detected with 4',6diamidino-2-phenylindole (DAPI) diluted 1:1000. Control sections were subjected to the same procedure except the SBU-3 antibody was replaced with 5\% BSA in PBS. For each slide, nuclei and positive SBU-3 cells were counted from eight randomly selected areas (at $400 \times$ magnification). Cell counting was performed using a procedure with animal and treatment unknown to the examiner. 


\section{Statistical analysis}

The ratio of target gene/Gapdh (fg/fg) was used as a value for each sample and data were analyzed using the least square ANOVA by the general linear model procedures of SAS. The proportions TGC and positive SBU-3 cells were analyzed using the least square ANOVA by the general linear model procedures of SAS. Duncan's multiple range test was utilized to analyze values when significant differences in groups were found. A probability level of $P<0.05$ was defined as significant.

\section{Results}

\section{Quantification of Mash2, Hand1, INF- $\tau$, and PAG-9 mRNA at day 17}

To evaluate if the expression of trophoblast differentiation genes are altered in SCNT preimplanted bovine embryos, the relative abundance of Mash2 and Hand1 mRNA was compared among $\mathrm{AI}(n=6), \operatorname{IVF}(n=6)$, and SCNT $(n=8)$ day 17 embryos. In addition, IFN- $\tau$ and PAG-9 mRNA were evaluated to determine the trophoblast cell function among all the groups. To adjust for individual variation among samples, all genes were analyzed with reference to the housekeeping gene Gapdh. The relative abundance of Gapdh mRNA was similar for all groups (Fig. 1). The abundance of Mash2 mRNA was 2.5-fold greater in SCNT embryos than $\mathrm{AI}(P<0.05)$, whereas IVF embryos were not different among the three groups $(P>0.10$; Fig. $2 \mathrm{~A})$. Opposite of Mash2, Hand1 mRNA abundance in Al and IVF embryos were 2.5-fold greater than SCNT $(P<0.05$, Fig. 2A). Abundance of IFN- $\tau$ mRNA did not differ among groups (Fig. 2B), suggesting normal mononucleate cell function among all groups. The abundance of PAG-9 mRNA was undetectable in SCNT embryos, and twofold lower in the IVF group compared to $\mathrm{Al}(P<0.05$, Fig. $2 \mathrm{~B})$, indicating an alteration in TGC number or function in SCNT embryos. These results suggest abnormal or

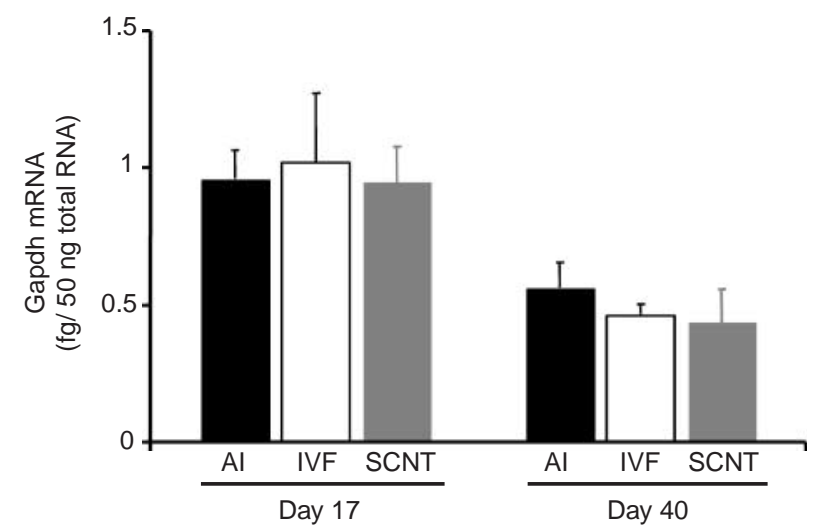

Figure 1 Histogram of glyceraldehyde 3-phosphate dehydrogenase (Gapdh) mRNA from artificial insemination (Al, black), in vitro produced (IVF, white), and somatic cell nuclear transfer (SCNT, grey) day 17 embryos and day 40 cotyledonary tissues.
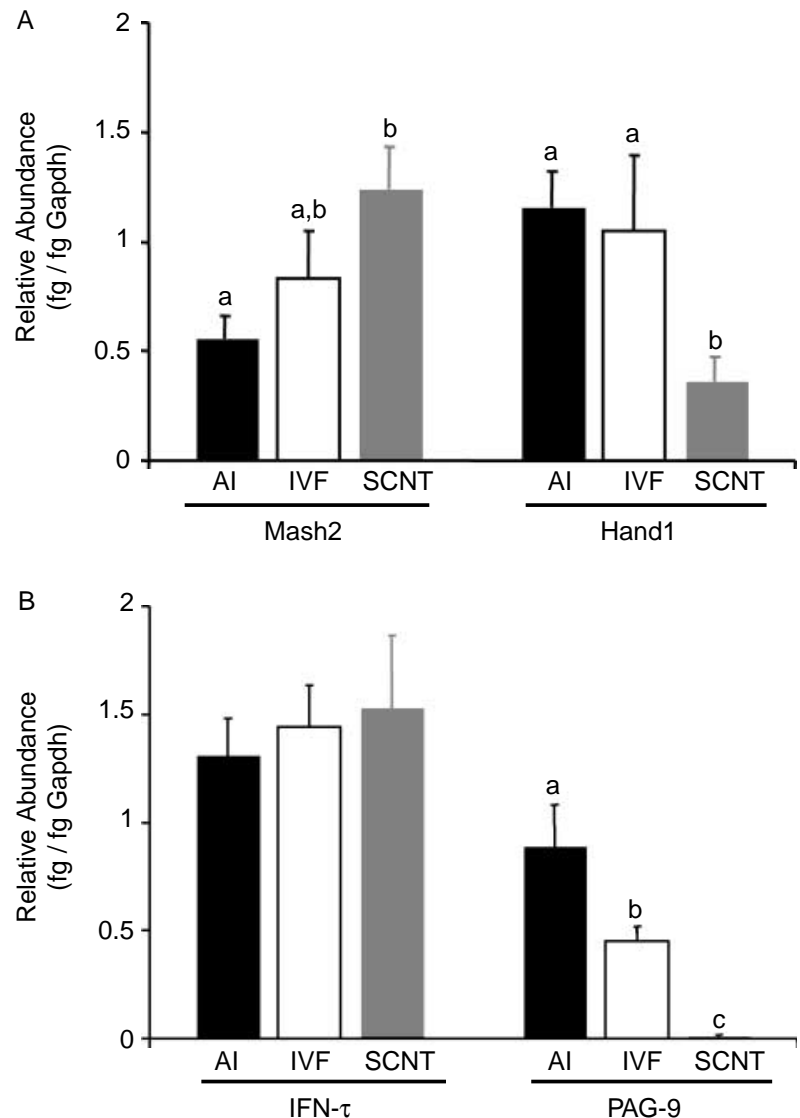

Figure 2 Relative abundance of mRNA of genes for (A) trophoblast development (Mash2 and Hand1) and (B) function (IFN- $\tau$ and PAG-9) in day $17 \mathrm{Al}$ (black), IVF (white), and SCNT (grey) embryos. Histograms represent $\mathrm{fg} / \mathrm{fg}$ Gapdh. The quantification represents means \pm S.E.M. of individual samples (AI and IVF, $n=6$; SCNT, $n=8$ ). Different superscripts represent significant differences in means $(P<0.05)$.

delayed trophoblast differentiation in embryos produced by SCNT.

\section{Quantification of Mash2 and Hand1 mRNA at day 40}

To determine if altered expression of Mash2 and Hand1 is normalized in SCNT embryos that survive past the time of implantation, cotyledonary tissues were collected from day 40 fetuses ( $n=3$ per group). The relative abundance of Mash2 and Hand1 mRNA was highest in SCNT cotyledons compared to IVF and Al cotyledons $(P<0.05$, Fig. 3$)$. These results indicate that Mash2 and Hand1 expression remains altered in SCNT embryos even though they successfully attach and develop placentomal structures.

\section{Parental allele expression of Mash2}

A single polymorphism detected between Bos taurus and Bos indicus Mash2 PCR products (Fig. 4A) was used to determine the parental origin of Mash2 by PCR-RFLP. At day 17, expression of Mash2 was found to be from both 


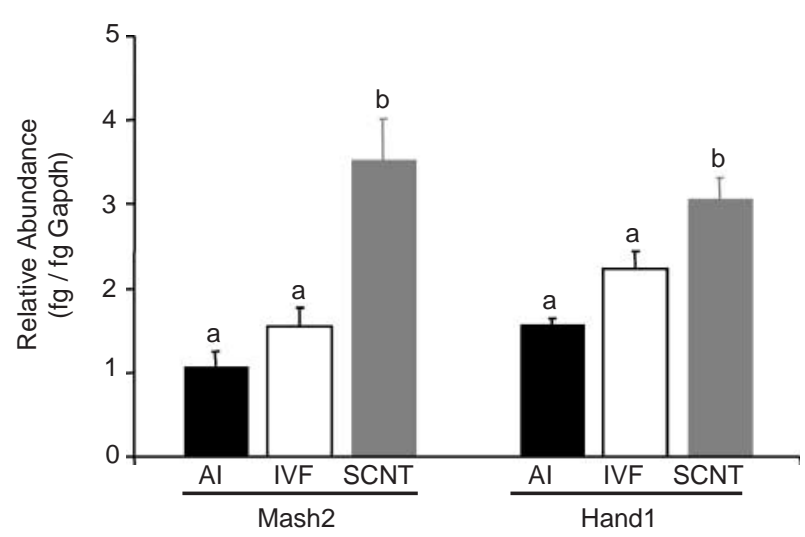

Figure 3 Relative abundance of Mash2 and Hand1 mRNA in day 40 cotyledonary tissues from Al (black), IVF (white), and SCNT (grey) embryos. Histograms represent fg/fg Gapdh. The quantification represents means \pm S.E.M. of individual samples ( $n=3$ /group). Different superscripts represent significant differences in means $(P<0.05)$.

paternal and maternal alleles regardless of group (Fig. 4B). However, the maternal allele appears to produce more Mash2 mRNA than the paternal allele (Fig. 4B). At day 40, the paternal Mash2 allele appears to be silenced, with a few embryos still expressing from both alleles, regardless of experimental group (Fig. 4C). These results indicate that the parental regulation of the bovine Mash2 gene is not altered in SCNT embryos.

\section{Trophoblast giant cell density and function}

To establish whether the altered gene expression of Mash2 and Hand1 correlates with modified trophoblast cell populations in bovine SCNT embryos, TGC densities and function were evaluated. Day 40 cotyledonary tissues from Al, IVF, and SCNT embryos were stained
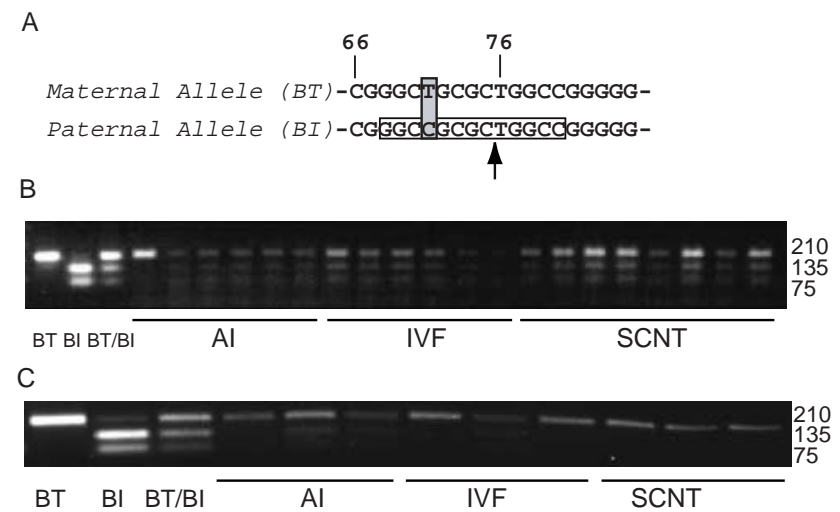

Figure 4 Analysis of parental expression of Mash2 in day 17 embryos and day 40 cotyledonary tissues by PCR-RFLP. (A) Single polymorphism difference (grey box) between the maternal (Bos taurus; BT) and paternal (Bos indicus; BI) Mash2 PCR products and recognition sequence (white box) for Sfil restriction enzyme (arrow indicates cleavage site). Digestion of Mash2 PCR products from day 60 Bos taurus, Bos indicus mixed BT/BI (M) cotyledonary tissue and AI, IVF, and SCNT day 17 embryos (B) and day 40 cotyledonary tissue (C). with PAS and counterstained with hematoxylin to determine the proportion of TGC in the trophectoderm (Fig. 5). No difference was detected in the percentage of the TGC in AI (Fig. 5A) and IVF (Fig. 5C) cotyledonary tissue $(P>0.10$; Table 2). However, the number of TGC in SCNT cotyledonary tissue (Fig. 5E) was reduced compared to the AI and IVF groups $(P<0.05$; Table 2$)$.

To confirm TGC populations and determine if TGC from SCNT cotyledonary tissues are functioning properly, the MAB to PAGs, SBU-3, was used. The SBU-3 antibody specifically labels trophoblast binucleate cells in placentomal region of ruminants (Lee et al. 1986). At day 40, cotyledonary tissue from Al fetuses had the highest percentage of positive cells (Fig. 5B; Table 2), followed by the IVF group (Fig. 5D; Table 2). Similar to the PAS staining, cotyledonary tissue from SCNT fetuses had the lowest proportion of positive cells (Fig. 5F; Table $2 ; P<0.01)$. These results suggest that there are fewer TGC in day 40 cotyledonary tissue from SCNT fetuses, but these cells are able to produce the TGCspecific protein, PAG.

\section{Discussion}

It has been well documented that cattle embryos produced by SCNT have abnormal placental development. These abnormalities are thought to be the major factors causing the high pregnancy loss associated with this procedure. Several studies have shown reduced number of placentomes and altered cellular organization of the SCNT placenta (Stice et al. 1996, Wells et al. 1999, Hill et al. 2000b, Hashizume et al. 2002). Till date much of the molecular research in SCNT pregnancies, past the blastocyst stage, has focused on the genes involved in the maternal/fetal interface, or those expressed by the TGC (Hashizume et al. 2002, Davies et al. 2004, Ravelich et al. 2004a, Hoffert et al. 2005, Oishi et al. 2006). In the present study, the focus was on genes believed to control development of the two principal trophoblast cell populations. In addition, the present study analyzes two time points during the periimplantation period that have been shown to be critical for successful placental development. The present data suggest that altered placental development of SCNT embryos may be due to the abnormal expression of genes that are crucial for normal trophoblast differentiation in the cow.

At day 17 of pregnancy in cattle, the trophoblast cells undergo rapid proliferation, resulting in elongation of the embryo throughout the uterus prior to attachment. It has been documented that the differentiation of the bovine trophoblast cells begins to occur during this time resulting in the production of the first TGC (Greenstein et al. 1958, Wathes \& Wooding 1980, Wooding 1983). Ruminant TGC play a critical role in the initial attachment and development of the maternal/fetal interface, as seen in other species, such as the mouse 

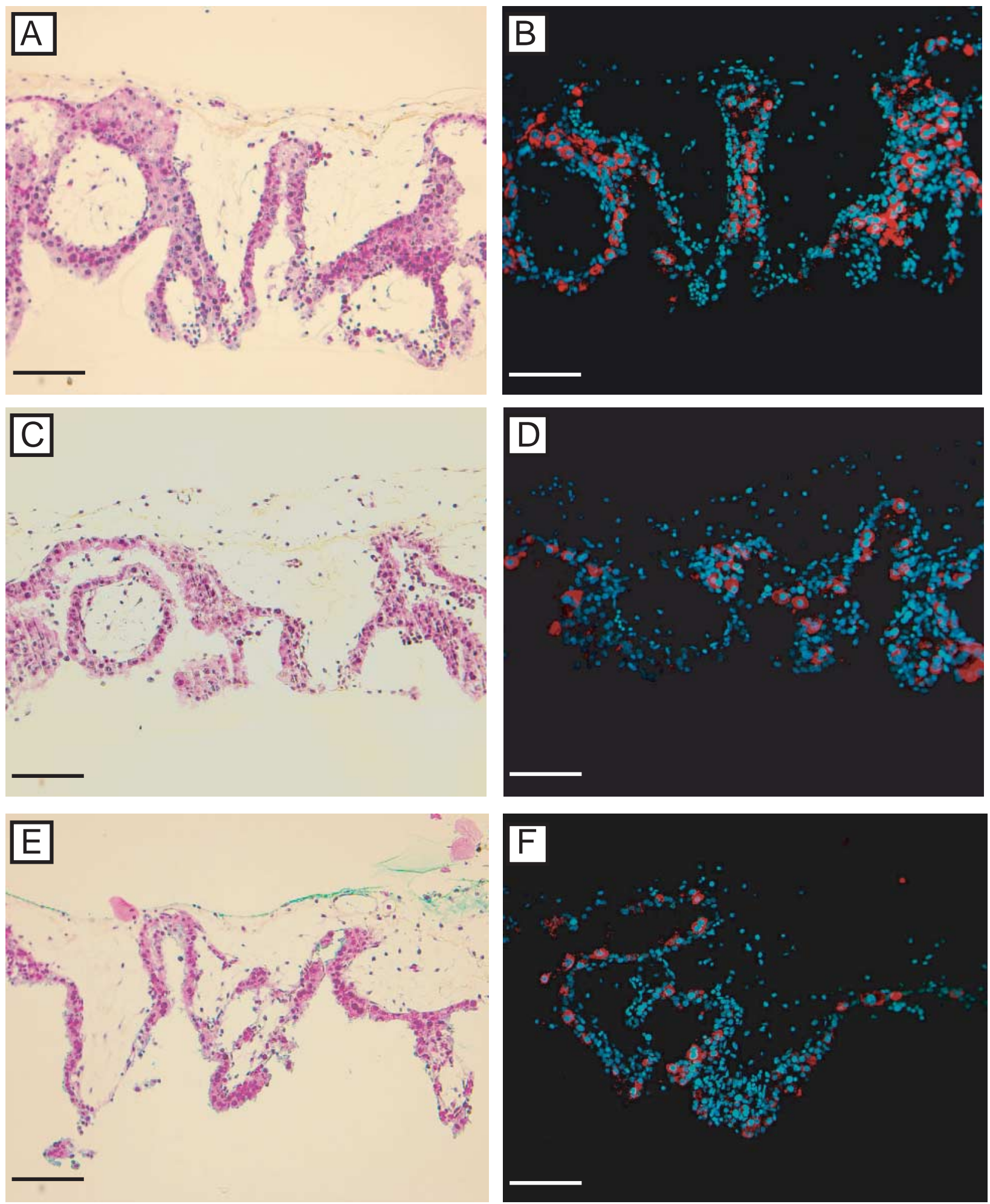

Figure 5 Immunohistochemical characterization of trophoblast binucleate/giant cells (TGC) in cotyledonary tissue from day $40 \mathrm{Al}$, IVF, and SCNT fetuses. Hematoxylin/PAS staining of AI (A), IVF (C), and SCNT (E) cotyledonary tissues. Positive TGC for SBU-3 (red) in AI (B), IVF (D), and SCNT (F) cotyledonary tissue. Nuclei counterstained with DAPI (blue). Bars $=100 \mu \mathrm{m}$. 
Table 2 Percentage of trophoblast giant cells and SBU-3 positive cells in day 40 cotyledonary tissue from embryos produced by artificial insemination (Al), in vitro fertilization (IVF), and somatic cell nuclear transfer (SCNT).

\begin{tabular}{llcc}
\hline Group & Animal $^{*}$ & TGC/total cells $(\%)$ & SBU-3 positive/nuclei $(\%)$ \\
\hline AI & 8 & $403 / 2076(19.4 \%)$ & $604 / 4109(14.7 \%)$ \\
& 4 & $385 / 2110(18.3 \%)$ & $644 / 4426(14.6 \%)$ \\
& 2 & $482 / 2614(18.4 \%)$ & $598 / 3980(15.0 \%)$ \\
IVF & Group total & $1270 / 6800(18.7 \%)^{\mathrm{a}}$ & $1846 / 12515(14.8 \%)^{\mathrm{a}}$ \\
& 9 & $334 / 2076(16.1 \%)$ & $409 / 4235(9.7 \%)$ \\
& 1 & $354 / 1966(18.0 \%)$ & $358 / 3987(9.0 \%)$ \\
& 5 & $383 / 2240(17.1 \%)$ & $477 / 4482(10.6 \%)$ \\
SCNT & Group total & $1071 / 6282(17.1 \%)^{\mathrm{a}}$ & $1244 / 12704(9.8 \%)^{\mathrm{b}}$ \\
& 7 & $288 / 2079(13.9 \%)$ & $395 / 5283(7.5 \%)$ \\
& 6 & $219 / 1832(12.0 \%)$ & $187 / 3423(5.5 \%)$ \\
& 3 & $324 / 2145(15.1 \%)$ & $316 / 4628(6.8 \%)$ \\
& Group total & $831 / 6056(13.7 \%)^{\mathrm{b}}$ & $898 / 13334(6.7 \%)^{\mathrm{c}}$ \\
\hline
\end{tabular}

$\mathrm{a}, \mathrm{b}, \mathrm{c} P<0.05$.

${ }^{*}$ Four cotyledons per animal were evaluated.

(Sutherland 2003) and human (Janatpour et al. 1999). Two genes that play vital role in trophoblast differentiation are Mash2 and Hand1. Both of these genes are basic helix-loop-helix transcription factors and appear to exert opposing influences on trophoblast differentiation (Cross et al. 1995). Mash2 stimulates trophoblast proliferation and inhibits TGC formation (Guillemot et al. 1995), whereas Hand1 stimulates TGC development (Riley et al. 1998). As in other species, Mash2 is a placenta-specific gene in the cow (Arnold et al. 2006). In the present study, abundance of Mash2 was higher in day 17 SCNT embryos, compared to in vivo derived embryos. Day 17 IVF embryos appear to produce intermediate levels of Mash2 mRNA compared to SCNT and AI embryos. These results suggest that in vitro culturing may contribute to the altered expression of Mash2 and these differences are amplified in embryos produced by SCNT. Several reports have demonstrated that in vitro culturing of bovine embryos causes altered placental development, as well as large offspring syndrome (for review, see Farin et al. 2004). The present results support the previous findings that Mash2 expression from day 8 blastocyst stage SCNT embryos, produced with G0/G1 donor cells, was elevated compared to IVF blastocyst embryos (Wrenzycki et al. 2001). Contradictory to the latter report, day $17 \mathrm{Al}$ embryos had less Mash2 mRNA than IVF-produced embryos. These differences may be due to the stage of embryogenesis analyzed. In addition, the present study directly compared SCNT, IVF, and AI embryos and distinguished the differences due to SCNT or in vitro culturing and their ability to develop in vivo to day 17 . These data indicate that SCNT embryos were unable to correctly express genes important to trophoblast development and in vitro culturing required to produce these embryos magnified these expression differences.

We have shown herein that expression of Hand 1 is reduced in day 17 SCNT embryos compared to both AI and IVF embryos. Hand1 has been shown to be required for the differentiation of trophoblast cells to giant cells in other species. In the mouse, Hand1 mutants arrest development around 7.5 days postcoitum and have significantly reduced number of trophoblast giant cells (Riley et al. 1998). In the cattle, expression of Hand1 mRNA is not detected until the embryonic oviod stage at day 12 postinsemination (Degrelle et al. 2005). The increase in Hand1 expression during this stage of development coincides with the differentiation of the trophoblast cells into TGC prior to implantation. This raises the possibility that the balance between the antipodal actions of Hand1 and Mash2 determines the differentiation of the trophoblast cell. Cross et al. (1995) reported that Rcho-1 trophoblast cell lines transfected to overexpress Hand1 differentiated into giant cells. Giant cell development was inhibited when Hand1-expressing Rcho- 1 cells co-expressed Mash2 (Cross et al. 1995). The reduced abundance of Hand1 mRNA and the elevated abundance of Mash2 in SCNT day 17 embryos suggests limitation in the capacity of trophoblast cells to differentiate into TGC. Another potential explanation is that the overall development is delayed in SCNT embryos relative to that seen in in vivo derived embryos. Till date, evaluation of the developmental status of bovine SCNT embryos has relied primarily on overall appearance (i.e., days to reach blastocyst stage and trophoblast: inner cell mass ratios). If there is in fact a delay in expression of vital development genes, as our data suggest that this may cause asynchrony between the embryo and recipient. This factor, in itself, may explain the greater pregnancy losses associated with SCNT pregnancy. In contrast, pregnancy rates did not change when day 8 blastocyst stage SCNT embryos were transferred into recipient cows at day 7 of the estrous cycle (DR Arnold, unpublished observations). This further suggests that differences seen in the present experiment are due to altered expression of the genes of interest and not to delays in development.

To examine trophoblast cell function, evaluation of expression of genes known to be exclusive to mononucleate cells (IFN- $\tau$ ) and TGC (PAG-9) was employed. IFN- $\tau$, a secretory protein that inhibits the normal luteal regression, is a marker of trophoblast cell function early in gestation (Helmer et al. 1987, Roberts et al. 1992). IFN- $\tau$ mRNA expression is first seen around the time of blastocoel formation (Hernandez-Ledezma et al. 1992), and continues until just prior to attachment around days 25-28 of gestation, with the greatest expression during days 16-18 (Roberts et al. 1992). In the present study, no differences in IFN- $\tau$ mRNA expression were detected among day $17 \mathrm{AI}, \mathrm{IVF}$, and SCNT embryos. These results indicate that mononucleate trophoblast cells in the SCNT embryos function normally with respect to expression of IFN- $\tau$, thus aberrant maternal recognition of pregnancy may not account for the increased early pregnancy loss in SCNT embryos. In contrast, Stojkovic 
et al. (1999) reported that in cultures, in vivo, IVF and SCNT embryos produce IFN $-\tau$ in a linear manner from days 11 to 15 . However, after day 15, IFN- $\tau$ production from cloned embryos levels off, whereas in vivo and in vitro derived embryos continue to produce IFN- $\tau$ through day 23 (Stojkovic et al. 1999). In their experiments, embryos were cultured in vitro for the entire 23 days and did not elongate after day 9, as seen in vivo. In the present study, a more physiological model was employed in which embryos were transferred into recipient cows and allowed to develop in vivo until day 17, resulting in appropriate elongation. It has been reported that female bovine blastocysts produced twice as much IFN- $\tau$ as do male blastocysts (Larson et al. 2001). In the present study, the SCNT embryos had a male genotype, since the donor cells were derived from a day 60 male fetus. As we did not determine the sex of the $\mathrm{Al}$ and IVF embryos, it is not possible to determine if IFN- $\tau$ mRNA abundance results were effected by the sex of the embryos. Other researchers have reported that by day 14 the differences in IFN- $\tau$ due to sex are no longer apparent (Kimura et al. 2004) suggesting in the present study IFN- $\tau$ mRNA levels at day 17 are not different for the male and female embryos.

The expression of a pregnancy-associated glycoprotein isoform (PAG-9) mRNA was used as a marker of TGC function in day 17 embryos. Several isoforms of PAGs have been identified and they exhibit unique temporal and spatial expression patterns during pregnancy (Green et al. 2000). Of the 21 different isoforms, PAG-9 is expressed only by TGC as early as day 25 of gestation (Green et al. 2000) and appears to be the predominant PAG expressed at this time (Patel et al. 2004a). In this study, expression of PAG-9 mRNA was detected in day $17 \mathrm{Al}$ embryos, but was undetectable in SCNT embryos. This concurs with reports that expression of PAG-1 and PAG-9 is lower in day 30 placental tissues of SCNT embryos compared to Al embryos (Patel et al. 2004b). The present study suggests that, in day 17 SCNT embryos, either no TGC are present or the TGC that are present are not functioning normally in terms to PAG-9 production. The specific role of PAGs in gestation remains unknown, however, some studies suggest that it may play a role in maternal immunosuppression during pregnancy (Dosogne et al. 2000). Evaluation of the inability of SCNT conceptuses to suppress the maternal immune system, allowing for normal maternal/fetal interaction awaits further examination.

To determine if altered expression of these genes are sustained as development continues, we chose to analyze cotyledonary tissue at day 40 of gestation, during the early phase of placentome formation. Abundance of Mash2 mRNA remained elevated in the SCNT group relative to both the IVF and AI groups. This sustained elevation suggests that either epigenetic regulation of Mash2 was not correctly reprogrammed in the donor cell or genes that regulate Mash2 were altered due to SCNT. Incomplete epigenetic reprogramming has been proposed to cause altered $X$ chromosome inactivation and bi-allelic expression of the maternally expression X-linked monoamine oxidase type A gene in placental tissue of deceased cloned cattle (Xue et al. 2002). In the present study, bi-allelic expression of Mash2 observed in all day 17 samples supports data suggesting that bovine Mash2 is expressed by both alleles prior to implantation and maternally expressed after implantation (Arnold et al. 2006). At day 40, the paternal allele of Mash2 appears to be silenced, even though low levels of paternal expression were detected in a few samples, regardless of group. These data indicate that altered Mash2 expression may be due to genes that regulate Mash2 and not to direct alteration of the imprinting status of Mash2.

By day 40, the abundance of Hand 1 has become higher in the SCNT group relative to the $\mathrm{Al}$ and IVF controls. If Mash2 and Hand1 function as opposing factors (Cross et al. 1995), the higher Hand1 expression could be a response to the elevated Mash2 mRNA in SCNT trophoblast. Similar to the data that overexpressing Hand1 Rcho-1 cells that co-expressed Mash2 had inhibited giant cell development (Cross et al. 1995), the SCNT trophoblast cells may not be able to stimulate TGC differentiation.

With evidence for altered expression of Mash2 and Hand1 mRNA in SCNT embryos and cotyledonary tissue, the next question to ask is how may these differences affect TGC densities and function. Klisch et al. (1999) reported that bovine TGC could be identified; by the number of nuclei, by the shape of the cell, and by the presence of PAS positive granules within the cells. These criteria were utilized in the present study to determine differences in TGC densities. The cotyledonary tissue from SCNT embryos contained fewer TGC than the Al and IVF samples. The values for the AI samples are similar to those reported by other researchers (Wooding 1982, 1983). Other investigators have reported no differences between TGC cell numbers for IVF and SCNT day 30 samples (Hoffert et al. 2005). These authors nonetheless reported higher than expected numbers of TGC for both groups (26 and $25.7 \%$ for SCNT and IVF samples respectively). These differences may be due to the type of tissue analyzed or the embryo culturing protocols. In the present study, day 40 of gestation was chosen so that the cotyledonary tissue would be more developed and could be distinguished from the intercotyledonary tissue. In addition, only the fetal placental tissue was analyzed. Even though the day 40 placentome allowed for the identification of the placentomes, the interdigitation at this time is rudimentary, allowing for fetal and maternal tissues to be separated. Additionally, the present study employed in vitro culture of the IVF and SCNT groups through to the blastocyst stage (day 8), whereas Hoffert et al. (2005) cultured embryos to the blastocyst stage in ligated 
sheep oviducts to mimic in vivo conditions. To address any effects due to in vitro culturing (for review, see Farin et al. 2004) in the present study, in vivo produced embryos were also analyzed. The densities of TGC were similar between the AI and IVF groups, indicating that the reduced number of TGC in the SCNT samples were due primarily to the cloning procedure.

To further analyze TGC densities and determine whether TGC from SCNT cotyledons were functioning properly, a MAB that recognizes PAG was employed (Lee et al. 1986). Similar to the density of TGC, SCNT cotyledonary tissue had fewer positive cells than its $\mathrm{Al}$ and IVF counterparts. Interestingly, the IVF group had fewer positive cells than did the Al. In contrast to these findings, Ravelich et al. (2004a), reported greater numbers of fetal, maternal, and binucleate cells in NT placentomes at days 50,100, and 150, compared to $\mathrm{Al} /$ IVF controls. These differences may be due to the days examined and the proteins detected. In the present study, we utilized a MAB that specifically recognizes PAGs from binucleate/giant cells in the cotyledonary region (Lee et al. 1986), whereas the latter study utilized immunostaining for bovine placental lactogen (Ravelich et al. 2004a). The data provided in the present study support the in situ hybridization data that PAG mRNA is reduced in cotyledonary tissue of day 60 SCNT placentas compared to Al controls (Hashizume et al. 2002). It further suggests that TGC from SCNT cotyledonary tissue are able to function similar to $\mathrm{Al}$ and IVF TGC, with respect to PAG production. However, with the reduced number of cells to produce PAG, overall SCNT placental function may be compromised. As stated above, the function of PAGs is not fully understood. However, Chavatte-Palmer et al. (2006) reported lower serum PAG concentrations in recipients which experienced early pregnancy loss (between days 35 and 90 of gestation) of SCNT fetuses. Incidentally, recipients who carried SCNT pregnancies to term had higher concentrations of PAG early in gestation compared to IVF controls (ChavattePalmer et al. 2006). These results may explain the differences in the present study with those previously reported using placental lactogen as a marker (Ravelich et al. 2004b). It must be kept in mind that $75 \%$ SCNT embryos did not survive to day 40 in the present investigation. It is possible that the embryos available for study after this time survived because sufficient numbers of TGC were present to allow for implantation and cotyledon development to occur.

In summary, we provide new information to demonstrate that genes critical for trophoblast proliferation (Mash2) and differentiation (Hand1) are aberrantly expressed in embryos derived from SCNT, which have recognizable placental abnormalities. In addition, trophoblast giant cell development is reduced in SCNT cotyledonary tissues. We believe that a plausible mechanism for altered trophoblast development in SCNT bovine embryos is the incomplete epigenetic reprogramming of the donor cells. This altered reprogramming (either directly or indirectly) may cause the Mash2 gene to be overexpressed and the expression of Hand 1 to be delayed early in development and overexpressed as pregnancy progresses. This series of events mimics those seen in mouse models where no Hand1 early in development leads to embryonic death due to reduced giant cell formation. We further report that placental tissues from SCNT fetuses had fewer TGC. Fewer TGC cause a reduction in overall PAG production, which could in itself cause an inability of the fetal unit to immunosuppress the maternal environment, leading to pregnancy loss commonly associated with nuclear transfer. By understanding the underlying molecular events involved in bovine trophoblast development, we can gain insight into the regulatory mechanisms involved in successful placentation and how these events may be manipulated to improve assisted reproductive techniques, such as SCNT.

\section{Acknowledgements}

The authors would like to thank Mr Garry Barcham and Dr Chee Seong Lee (University of Melbourne; Victoria, Australia) for kindly providing the SBU-3 antibody, Dr Flavio Meirelles (Universidade de São Paulo, Pirassununga, SP, Brazil) for providing the Bos indicus cotyledonary tissue and Carmen Léveillée and Jacinthe Therrien for laboratory assistance. This work was supported by the Natural Sciences and Engineering Research Council of Canada Strategic grant STPGP 269864-03 (LCS and BDM.) and by the Program on Oocyte Health (www. ohri.ca/oocyte) funded under the Healthy Gametes and Great Embryos Strategic Initiative of the Canadian Institutes of Health Research (CIHR) Institute of Human Development, Child and Youth Health (IHDCYH), grant number HGG62293 (LCS). The authors declare that there is no conflict of interest that would prejudice the impartiality of this scientific work.

\section{References}

Arnold DR, Lefebvre R \& Smith LC 2006 Characterization of the placenta specific bovine mammalian achaete scute-like homologue 2 (Mash2) gene. Placenta [in press].

Bordignon V, Keyston R, Lazaris A, Bilodeau AS, Pontes JH, Arnold D, Fecteau G, Keefer C \& Smith LC 2003 Transgene expression of green fluorescent protein and germ line transmission in cloned calves derived from in vitro-transfected somatic cells. Biology of Reproduction 68 2013-2023.

Chavatte-Palmer P, de Sousa N, Laigre P, Camous S, Ponter AA, Beckers JF \& Heyman Y 2006 Ultrasound fetal measurements and pregnancy associated glycoprotein secretion in early pregnancy in cattle recipients carrying somatic clones. Theriogenology [in press].

Cross JC, Flannery ML, Blanar MA, Steingrimsson E, Jenkins NA, Copeland NG, Rutter WJ \& Werb Z 1995 Hxt encodes a basic helixloop-helix transcription factor that regulates trophoblast cell development. Development 121 2513-2523.

Davies CJ, Hill JR, Edwards JL, Schrick FN, Fisher PJ, Eldridge JA \& Schlafer DH 2004 Major histocompatibility antigen expression on the bovine placenta: its relationship to abnormal pregnancies and retained placenta. Animal Reproduction Science 82-83 267-280. 
De Sousa PA, King T, Harkness L, Young LE, Walker SK \& Wilmut I 2001 Evaluation of gestational deficiencies in cloned sheep fetuses and placentae. Biology of Reproduction 65 23-30.

Degrelle SA, Campion E, Cabau C, Piumi F, Reinaud P, Richard C, Renard JP \& Hue I 2005 Molecular evidence for a critical period in mural trophoblast development in bovine blastocysts. Developmental Biology 288 448-460.

Dosogne H, Massart-Leen AM \& Burvenich C 2000 Immunological aspects of pregnancy-associated glycoproteins. Advances in Experimental Medicine and Biology 480 295-305.

Farin CE, Farin PW \& Piedrahita JA 2004 Development of fetuses from in vitro-produced and cloned bovine embryos. Journal of Animal Science 82 E53-E62.

Gardner DK, Lane M, Spitzer A \& Batt PA 1994 Enhanced rates of cleavage and development for sheep zygotes cultured to the blastocyst stage in vitro in the absence of serum and somatic cells: amino acids, vitamins, and culturing embryos in groups stimulate development. Biology of Reproduction 50 390-400.

Green JA, Xie S, Quan X, Bao B, Gan X, Mathialagan N, Beckers JF \& Roberts RM 2000 Pregnancy-associated bovine and ovine glycoproteins exhibit spatially and temporally distinct expression patterns during pregnancy. Biology of Reproduction 62 1624-1631.

Greenstein JS, Murray RW \& Foley RC 1958 Observations on the morphogenesis and histochemistry of the bovine preattachment placenta between 16 and 33 days of gestation. The Anatomical Record 132 321-341.

Guillemot F, Nagy A, Auerbach A, Rossant J \& Joyner AL 1994 Essential role of Mash-2 in extraembryonic development. Nature 371 333-336.

Guillemot F, Caspary T, Tilghman SM, Copeland NG, Gilbert DJ, Jenkins NA, Anderson DJ, Joyner AL, Rossant J \& Nagy A 1995 Genomic imprinting of Mash2, a mouse gene required for trophoblast development. Nature Genetics 9 235-242.

Hashizume K, Ishiwata H, Kizaki K, Yamada O, Takahashi T, Imai K, Patel OV, Akagi S, Shimizu M, Takahashi S, et al. 2002 Implantation and placental development in somatic cell clone recipient cows. Cloning and Stem Cells 4 197-209.

Helmer SD, Hansen PJ, Anthony RV, Thatcher WW, Bazer FW \& Roberts RM 1987 Identification of bovine trophoblast protein-1, a secretory protein immunologically related to ovine trophoblast protein-1. Journal of Reproduction and Fertility 79 83-91.

Hernandez-Ledezma JJ, Sikes JD, Murphy CN, Watson AJ, Schultz GA \& Roberts RM 1992 Expression of bovine trophoblast interferon in conceptuses derived by in vitro techniques. Biology of Reproduction 47 374-380.

Heyman Y 2005 Nuclear transfer: a new tool for reproductive biotechnology in cattle. Reproduction, Nutrition, Development 45 353-361.

Hill JR, Winger QA, Long CR, Looney CR, Thompson JA \& Westhusin ME 2000a Development rates of male bovine nuclear transfer embryos derived from adult and fetal cells. Biology of Reproduction 62 1135-1140.

Hill JR, Burghardt RC, Jones K, Long CR, Looney CR, Shin T, Spencer TE, Thompson JA, Winger QA \& Westhusin ME 2000b Evidence for placental abnormality as the major cause of mortality in first-trimester somatic cell cloned bovine fetuses. Biology of Reproduction 63 1787-1794.

Hoffert KA, Batchelder CA, Bertolini M, Moyer AL, Famula TR, Anderson DL \& Anderson GB 2005 Measures of maternal-fetal interaction in day-30 bovine pregnancies derived from nuclear transfer. Cloning and Stem Cells 7 289-305.

Itoh N, Patel U \& Skinner MK 1998 Developmental and hormonal regulation of transforming growth factor-alpha and epidermal growth factor receptor gene expression in isolated prostatic epithelial and stromal cells. Endocrinology 139 1369-1377.

Janatpour MJ, Utset MF, Cross JC, Rossant J, Dong J, Israel MA \& Fisher SJ 1999 A repertoire of differentially expressed transcription factors that offers insight into mechanisms of human cytotrophoblast differentiation. Developmental Genetics 25 146-157.
Kessler MA \& Schuler LA 1991 Structure of the bovine placental lactogen gene and alternative splicing of transcripts. DNA and Cell Biology 10 93-104.

Kimura K, Spate LD, Green MP, Murphy CN, Seidel GE Jr \& Roberts RM 2004 Sexual dimorphism in interferon-tau production by in vivoderived bovine embryos. Molecular Reproduction and Development 67 193-199.

Klisch K, Pfarrer C, Schuler G, Hoffmann B \& Leiser R 1999 Tripolar acytokinetic mitosis and formation of feto-maternal syncytia in the bovine placentome: different modes of the generation of multinuclear cells. Anatomy and Embryology 200 229-237.

Larson MA, Kimura K, Kubisch HM \& Roberts RM 2001 Sexual dimorphism among bovine embryos in their ability to make the transition to expanded blastocyst and in the expression of the signaling molecule IFN-tau. PNAS 98 9677-9682.

Lee CS, Gogolin-Ewens K, White TR \& Brandon MR 1985 Studies on the distribution of binucleate cells in the placenta of the sheep with a monoclonal antibody SBU-3. Journal of Anatomy 4 565-576.

Lee CS, Gogolin-Ewens K \& Brandon MR 1986 Comparative studies on the distribution of binucleate cells in the placentae of the deer and cow using the monoclonal antibody, SBU-3. Journal of Anatomy 147 163-179.

McLaren A 1990 The Embryo, Cambridge, UK: Cambridge University Press.

Ogura A, Inoue K, Ogonuki N, Lee J, Kohda T \& Ishino F 2002 Phenotypic effects of somatic cell cloning in the mouse. Cloning and Stem Cells 4 397-405.

Oishi M, Gohma H, Hashizume K, Taniguchi Y, Yasue H, Takahashi S, Yamada T \& Sasaki Y 2006 Early embryonic death-associated changes in genome-wide gene expression profiles in the fetal placenta of the cow carrying somatic nuclear-derived cloned embryo. Molecular Reproduction and Development 73 404-409.

Ono Y, Shimozawa N, Ito M \& Kono T 2001 a Cloned mice from fetal fibroblast cells arrested at metaphase by a serial nuclear transfer. Biology of Reproduction 64 44-50.

Ono Y, Shimozawa N, Muguruma K, Kimoto S, Hioki K, Tachibana M, Shinkai Y, Ito M \& Kono T $2001 b$ Production of cloned mice from embryonic stem cells arrested at metaphase. Reproduction 122 731-736.

Parrish JJ, Susko-Parrish JL, Leibfried-Rutledge ML, Critser ES, Eyestone WH \& First NL 1986 Bovine in vitro fertilization with frozen-thawed semen. Theriogenology 25 591-600.

Patel OV, Yamada O, Kizaki K, Takahashi T, Imai K \& Hashizume K 2004a Quantitative analysis throughout pregnancy of placentomal and interplacentomal expression of pregnancy-associated glycoproteins- 1 and -9 in the cow. Molecular Reproduction and Development 67 257-263.

Patel OV, Yamada O, Kizaki K, Takahashi T, Imai K, Takahashi S, Izaike Y, Schuler LA, Takezawa T \& Hashizume K 2004b Expression of trophoblast cell-specific pregnancy-related genes in somatic cellcloned bovine pregnancies. Biology of Reproduction 70 1114-1120.

Price CA, Carriere PD, Gosselin N, Kohram H \& Guilbault LA 1999 Effects of superovulation on endogenous $\mathrm{LH}$ secretion in cattle, and consequences for embryo production. Theriogenology 51 37-46.

Ravelich SR, Breier BH, Reddy S, Keelan JA, Wells DN, Peterson AJ \& Lee RS 2004a Insulin-like growth factor-I and binding proteins 1, 2 , and 3 in bovine nuclear transfer pregnancies. Biology of Reproduction 70 430-438.

Ravelich SR, Shelling AN, Ramachandran A, Reddy S, Keelan JA, Wells DN, Peterson AJ, Lee RS \& Breier BH 2004b Altered placental lactogen and leptin expression in placentomes from bovine nuclear transfer pregnancies. Biology of Reproduction 71 1862-1869.

Riley P, Anson-Cartwright L \& Cross JC 1998 The Hand1 bHLH transcription factor is essential for placentation and cardiac morphogenesis. Nature Genetics 18 271-275.

Roberts RM, Cross JC \& Leaman DW 1992 Interferons as hormones of pregnancy. Endocrine Reviews 13 432-452. 
Rossant J, Guillemot F, Tanaka M, Latham K, Gertenstein M \& Nagy A 1998 Mash2 is expressed in oogenesis and preimplantation development but is not required for blastocyst formation. Mechanisms of Development 73 183-191.

Stice SL, Strelchenko NS, Keefer CL \& Matthews L 1996 Pluripotent bovine embryonic cell lines direct embryonic development following nuclear transfer. Biology of Reproduction 54 100-110.

Stojkovic M, Buttner M, Zakhartchenko V, Riedl J, Reichenbach HD, Wenigerkind H, Brem G \& Wolf E 1999 Secretion of interferon-tau by bovine embryos in long-term culture: comparison of in vivo derived, in vitro produced, nuclear transfer and demi-embryos. Animal Reproduction Science 55 151-162.

Sutherland A 2003 Mechanisms of implantation in the mouse: differentiation and functional importance of trophoblast giant cell behavior. Developmental Biology 258 241-251.

Tanaka M, Gertsenstein M, Rossant J \& Nagy A 1997 Mash2 acts cell autonomously in mouse spongiotrophoblast development. Developmental Biology 190 55-65.

Wathes DC \& Wooding FB 1980 An electron microscopic study of implantation in the cow. American Journal of Anatomy 159 285-306.

Wells DN, Misica PM \& Tervit HR 1999 Production of cloned calves following nuclear transfer with cultured adult mural granulosa cells. Biology of Reproduction 60 996-1005.

Wilmut I, Schnieke AE, McWhir J, Kind AJ \& Campbell KH 1997 Viable offspring derived from fetal and adult mammalian cells. Nature 385 810-813.

Wooding FB 1981 Localization of ovine placental lactogen in sheep placentomes by electron microscope immunocytochemistry. Journal of Reproduction and Fertility 62 15-19.
Wooding FB 1982 The role of the binucleate cell in ruminant placental structure. Journal of Reproduction and Fertility 31 31-39.

Wooding FB 1983 Frequency and localization of binucleate cells in the placentomes of ruminants. Placenta 4 527-539.

Wooding FB \& Wathes DC 1980 Binucleate cell migration in the bovine placentome. Journal of Reproduction and Fertility 59 425-430.

Wrenzycki C, Wells D, Herrmann D, Miller A, Oliver J, Tervit R \& Niemann H 2001 Nuclear transfer protocol affects messenger RNA expression patterns in cloned bovine blastocysts. Biology of Reproduction 65 309-317.

Wrenzycki C, Herrmann D, Lucas-Hahn A, Korsawe K, Lemme E \& Niemann H 2005 Messenger RNA expression patterns in bovine embryos derived from in vitro procedures and their implications for development. Reproduction, Fertility, and Development 17 23-35.

Xue F, Tian XC, Du F, Kubota C, Taneja M, Dinnyes A, Dai Y, Levine H, Pereira LV \& Yang X 2002 Aberrant patterns of X chromosome inactivation in bovine clones. Nature Genetics 31 216-220.

Zoli AP, Demez P, Beckers JF, Reznik M \& Beckers A 1992 Light and electron microscopic immunolocalization of bovine pregnancyassociated glycoprotein in the bovine placentome. Biology of Reproduction 46 623-629.

Received 6 April 2006

First decision 27 April 2006

Revised manuscript received 17 May 2006

Accepted 22 May 2006 